九州大学学術情報リポジトリ

Kyushu University Institutional Repository

Analys is of Sedimentary Facies and Paleogeographic Reconstruction of the Coherent and Chaotic Rock Bodies in the Shimanto Supergroup, SW Shikoku, Japan

The in, Myint

Department of Geology, University of Mandalay

https://doi.org/10.5109/1543639

出版情報: 九州大学大学院理学研究院紀要：Series D, Earth and planetary sciences. 27 (2)， pp. 75-99, 1992-02-14. Faculty of Science, Kyushu University

バージョン :

権利関係 : 


\title{
Analysis of Sedimentary Facies and Paleogeographic Reconstruction of the Coherent and Chaotic Rock Bodies in the Shimanto Supergroup, SW Shikoku, Japan
}

\author{
Mrint Thein*
}

\begin{abstract}
The Paleogene to Neogene sedimentaty rocks, defined here as the Kurusuno and Shimizu Formations, representing a part of the Shimanto Supergroup, in SW Shikoku, Japan, are composed of clastic sedimentary rocks. Each formation is subdivided into two lithologic facies such as chaotic facies and coherent facies. The chaotic facies is composed mainly of various blocks and clasts of sandstone, shale and rare limestone, volcanic breccia and conglomerate. The Kurusuno Formation is interpreted as a precursory olistostrome, whereas the Shimizu Formation as a composite olistostrome. The Kurusuno Formation consists mainly of sandstone and shale derived from the coherent facies deposited within the same sedimentary basin. On the other hand, the Shimizu Formation consists mainly of other different exotic blocks and clasts of older age that are derived from an uplifted accreted terranes.

The sedimentary facies and bedding features are observed in each coherent facies both of the Kurusuno and the Shimizu Formations. The Kurusuno Formation is interpreted as submarine channel and overbank deposits accumulated at the base of a slope depositional setting. The Shimizu Formation is interpreted as channel sediments showing inverse grading and inverse-to-normally grades, beds indicating that they are slope or slope basin deposits accumulated near a canyon mouth.

The abundant slump beds associated with pebbly mudstone within the turbidites also support that they are deposited together with this channel fill on a slope or within a slope basin. Both of the Kurusuno and Shimizu Formations are deposited as mass flows that initiate to transport reworked slope sediments or accreted trench deposits to the trench floor, commonly via small submarine canyons that head on the lower slope.
\end{abstract}

\section{Introduction}

One of the most characteristic features of submarine slope environment is the channel fill deposits (Stanley and UnRug, 1972; MutTi and Ricci-Lucchi, 1978). Dissecting fine grained sediments that dominate the slope environment, submarine channels and valley serve as conduits for coarse grained sediments to bypass the continental shelf (McGregor and Bennett, 1979; Dott and Bird, 1979). Some example of ancient trench inner slope deposits are also considered to be analogous,

* Present Address: Department of Geology, University of Mandalay, Mandalay, Myanmar.

Manuscript Received August 2, 1991. 


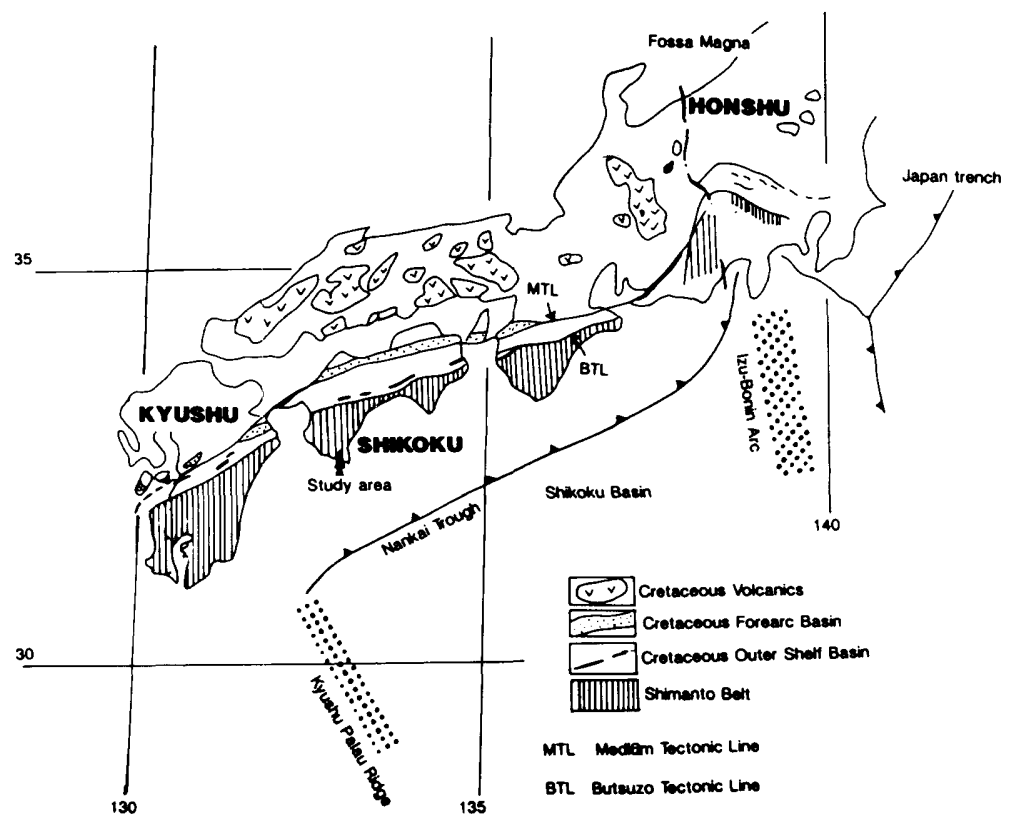

Fig. 1. Map of SW Japan showing the Cretaceous to Paleogene major morpho-tectonic belts and recent subduction zone (after Taira, 1985).

and such examples are encountered in the inner slope of the Middle America trench (KARIG et al., 1978), and the base of the trench slope at the Nias Island of Indonesia (KARIG et al., 1980 ; MOORE et al., 1980 ).

This paper describes the sedimentary and stratigraphic features of the Kurusuno and Shimizu Formations, based mainly on the observation along the coast range of the east Hata Peninsula (Fig. 1). The analysis verified and reconstructed the sedimentary setting for the formation of submarine channel fill, overbank fine-graned deposits, slope and slope basin deposits, all of which were redeposited as olistostromes in the inner trench wall due to gravity instability. Such conditions produced chaotic rock bodies, sandy and shaly turbidites. The chaotic rock bodies are defined here as rock masses of formational range. They are primarily interpreted as pebbly mudstones formed by debris flow. The slump deposits associated with pebbly mudstones of debris flow are also commonly recognized in the Paleogene-Neogene sequence, and those are involved within the chaotic facies.

\section{Geologic Setting}

In Japan, the Sangun and Yamaguchi Belts are parts of exotic terranes and/or subduction complexes juxtaposed against the ancient Asian continental margin in the pre-Jurassic time. The Chugoku, Chichibu, Tanba, Mino and Ashio Belts and their derivatives, Sambagawa and Ryoke and Sanbosan Belts, are mainly as the Jurassic subduction complexes (TAIRA, 1985). The Shimanto Belt is a well documented example of Cretaceous to Tertiary subduction complex which is juxtaposed with the Jurassic Sanbosan Belt (NISHI, 1990)(Fig. 1). 
The Cretaceous and Paleogene active margin of SW Japan formed five major morpho-tectonic belts as follows (TAIRA, 1981): (1) a belt of andesitic and rhyolitic extrusives and terrestrial sediments with widespread granitic intrusives, (2) a narrow, elongate belt of Upper Cretaceous marine clastic forearc basin, (3) non-magmatic outer arc, (4) outer arc shelf basin and (5) Shimanto subduction complex (Fig. 1).

The Shimanto Belt extends from the Boso Peninsula, near Tokyo, southwestwards to the Ryukyu Islands, and is mostly occupied by the Shimanto Supergroup (OGAWA, 1902 ; KaTTO, 1980). The supergroup is composed mainly of clastic "melange" which occasionally includes basaltic rocks and oceanic sedimentary rocks such as chert and limestone. They represent a variety of sedimentary and tectonic environments within a forearc-trench system (TAIRA, 1981; TAIRA et al., 1982; SuzUki and HADA, 1983, OgawA, 1985). The strata are disposed in steeply dipping fault-bounded structural packets that become younger towards the southwest, thus well match the definition of an accretionary prism (TAIRA et al., 1982).

Some parts of the Oligocene-Miocene rocks within the Shimanto Supergroup have been interpreted as a packet of composite olistostromes (KANMERA, 1977; SAKAI, 1988) that formed after subduction ceased during the opening of the Shikoku basin, and initiation of strike-slip movement along the margin (SAKAI, 1983).

The Shimanto Belt can be subdivided into two distinct belts; namely the Northern Shimanto Belt (Cretateous), and the Southern Shimanto Belt (Tertiary). These two belts are separated by the Nakasuji Tectonic Line in western Shikoku. The present study area lies on the southern part of the Hata Peninsula (Fig. 2), and contains Paleogene to Neogene clastic sedimentary strata.

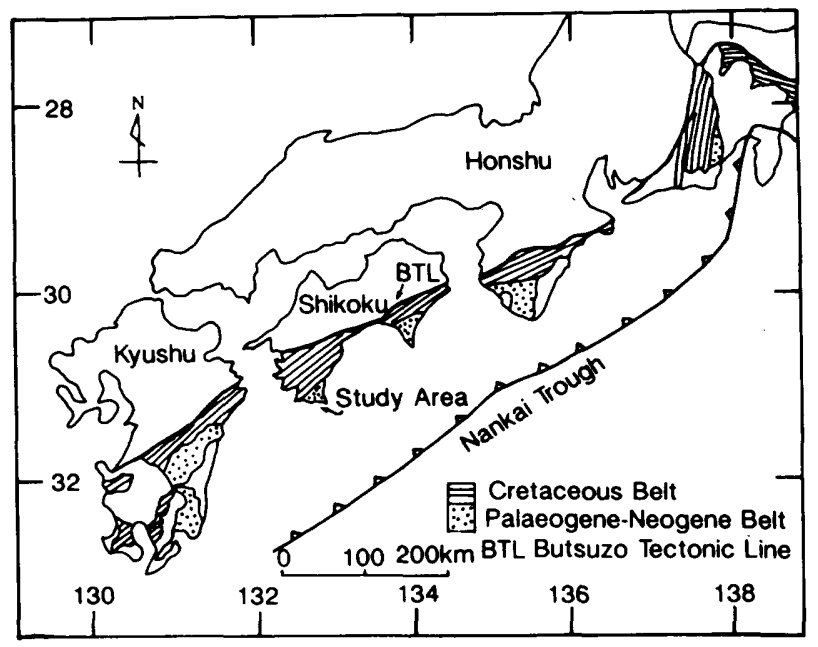

Fig. 2. Location and size of the study area. The area represents the eastern part of the Hata Peninsura, and is covered with Paleogene-Neogene clastic sedimentary strata. 
In the same area of this work, TAIRA et al. (1980) and KimURA (1985) sub-divided the Tertiary sediments into three distinct formations, namely the Kurusuno Formation, Shimizu Formation and Misaki Formation. Due to the chaotic sedimentary facies and various kinds of blocks of different ages in the Shimizu Formation, KIMURA (1985) interpreted that the Shimizu Formation is the submarine gravity slide deposits.

\section{Stratigraphy}

\section{Kurusuno Formation}

\section{Definition}

The Kurusuno Formation is firstly defined as the strata which are distributed in the whole northernmost portion of the study area (Fig. 3). The type section is situated at Kurusuno Village as proposed by Katтo and Mitsui (1976). The boundaries of this formation to the Misaki Group is thought to be unconformable (KIMURA, 1985). The boundary of this formation at the northwestern part of the Hata Peninsula is demarcated by fault contact with the Campanian-Maastrichtian Arioka Formation in the Nakamura-Tsukumo area. Also, its boundary at the eastern part of the Hata Peninsula is demarcated by fault contact with the Eocene Tanoguchi Formation (KatTo, 1961) in the north, and Oligocene Shimizu Formation in the Tosashimizu area (present study) in the south.

\section{Distribution and lithology}

The Kurusuno Formation is distributed from the line which passes through the Ohki-Yokomichi Villages at the middle part of the area, and to the line which passes through Kaigake-Kurusuno Villages at the northern parts of the area. It is well exposed along the Pacific Ocean coastline from Ohki beach to the river mouth of the Shimanto.

The Kurusuno Formation is sub-divided into two lithologic facies; namely the coherent facies and chaotic facies. Not only the coherent facies but also the chaotic one in this formation are composed mainly of interbeds of thin sandstone and mudstone interlayered with thick-bedded sandstone beds. Some strata of the chaotic facies contain small clasts of volcanic conglomerate and limestone exposed at the cape of Zaimisaki. Rocks of chaotic facies are distributed as the minor sequence and lenticular shaped rock bodies among the coherent one and distributed mainly in the northernmost parts of the area (Fig. 3).

\section{Age determination}

The age is inferred to be Middle to Late Eocene by larger foraminifera species Asterocyclina cf. stella from limestone at the Cape Zaimisaki $\left(32^{\circ} 52^{\prime} \mathrm{N}\right.$ Lat., $133^{\circ} 01^{\prime} \mathrm{E}$ Long.) (Matumaru, 1980). The slightly different species indicating Late Eocene are collected from another locality, $800 \mathrm{~m}$ to the south from Takahata Village (32 $49^{\prime} 55^{\prime \prime} \mathrm{N}$ Lat., $132^{\circ} 54^{\prime} 34^{\prime \prime} \mathrm{E}$ Long.) (Matsumaru and Kimura, 1989). The strata exposed at this locality were formerly designated as the Shimizu Formation, however, I now redefine as a part of the Kurusuno Formation, because the strata exposed in these two localities are lithologically and structurally very similar, and has a close age relationship. There- 
fore, the Kurusuno Formation may range the whole span of Eocene, and the boundary between the Kurusuno and Shimizu Formations can be replaced at the line which cuts across Yokomichi Village and the Ohki beach (Fig. 3).

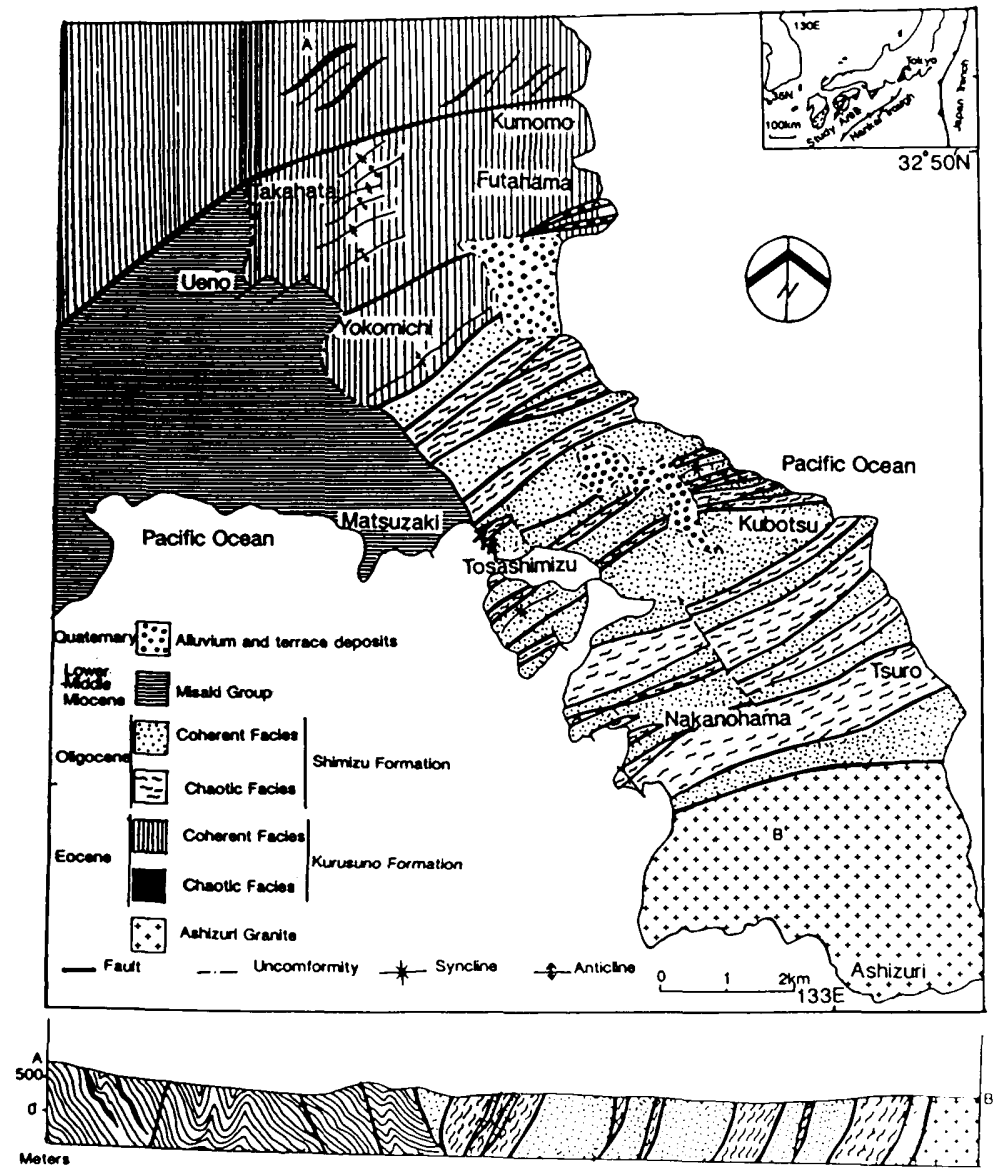

Fig. 3. Geological map of the study area representing the major rock distribution and the geological structure.

\section{Shimizu Formation}

\section{Definition}

The Shimizu Formation is defined as the strata which are distributed in the southeastern portion of the Hata Peninsula by Katto (1961). This name is continuously applied in this study. It is intruded by the Ashizuri Granite of $14 \mathrm{Ma}$ in age (TAKAHASHI, 1980) in the southern part of the area (Fig. 3). The western boundary is in contact with the Lower Miocene (Burdigalian) Misaki Formation, where the primary uncomformable boundary is modified by the later fault movement. Kimura(1985) firstly found the uncomformity between the Shimizu and Misaki Formations near Takahara Village. However, the faulted contact between these two formations is clearly visible in the stream of Ogawa, situated at $1 \mathrm{~km}$ north of Kakumi Village. 
This boundary fault and associated faults trend nearly NS and dip towards east (Fig. 3). They effect all of the strata in the Shimizu Formation as well as the Misaki Formation, hence, they are post dated after the deposition of the Misaki Fromation.

\section{Distribution and lithology}

The Shimizu Formation is distributed from the line that passes through the soutn of Ohama-Ohtani Villages at the southern part of the area, and to the line that passes through Ohki-Yokomichi Villages at the northern part of the area (Fig. 3). It is well
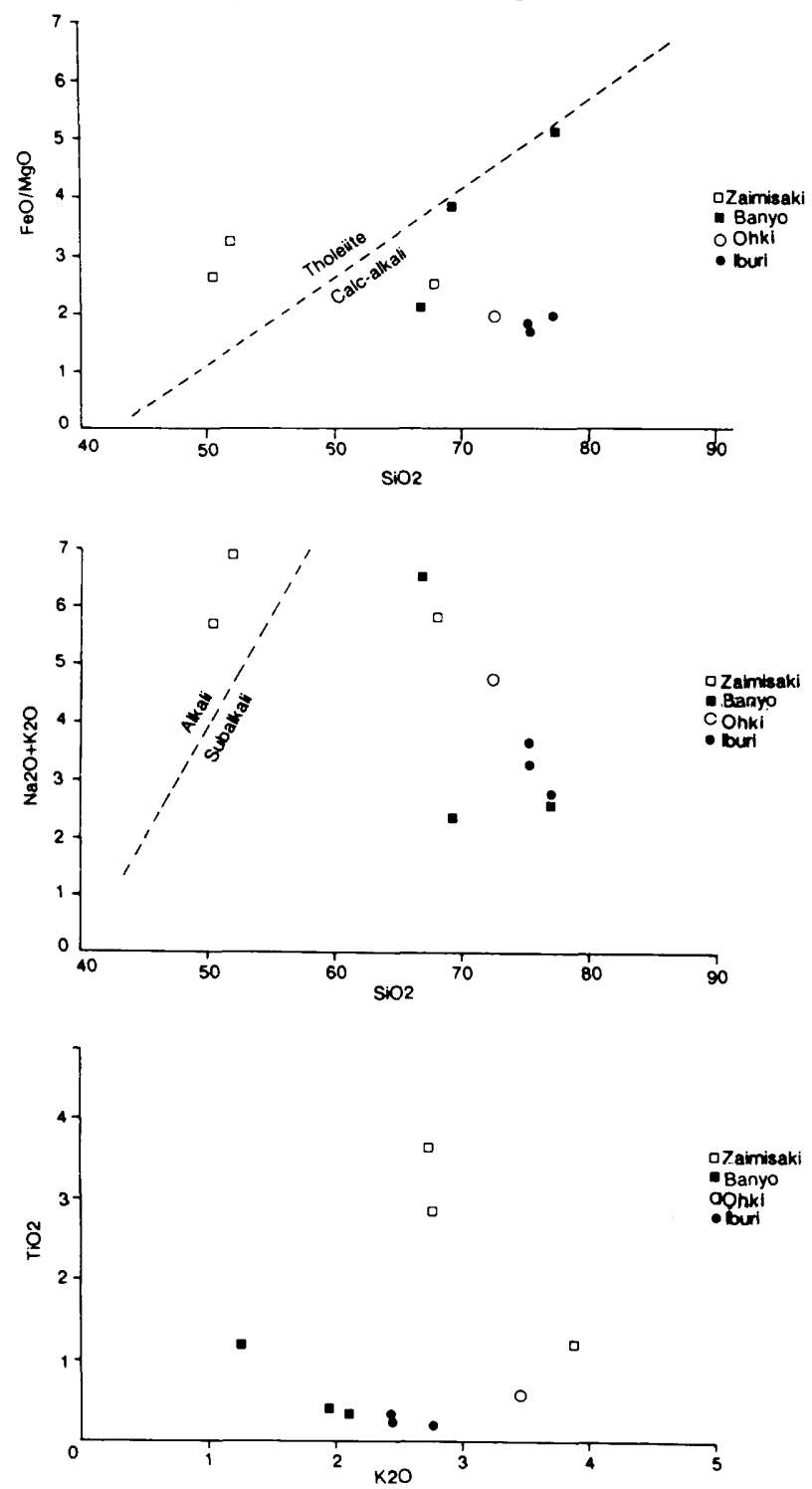

Fig. 4. Compositional diagram of the volcanic rocks of the Kurusuno and Shimizu Formations. Analysis was done on the directly fused glass sample of rocks by Electron Microprobe of Link EDS system with ZAF calibration. (a) $\mathrm{SiO}_{2}$ vs. FeO/MgO. The line dividing calc-alkaline and tholeiitic fields is after Miyashiro (1968). (b) $\mathrm{SiO}_{2}$ vs. total alkali. The line dividing alkali and sub-alkali fields is after Macdoanald (1968). (c) $\mathrm{TiO}_{2}$ vs $\mathrm{K}_{2} \mathrm{O}$. Most of the samples are in the calc-alkali trend. 
exposed at all the Pacific Ocean coast line of the southern portion of the study area.

The Shimizu Formation is subdivided into two lithologic facies, namely the coherent facies and the chaotic facies. The coherent facies exposed in three sections of Iburi, south of Iyodaba, and southeast of the Tosashimizu Port. The first two sections are composed mainly of thick-bedded to massive, disorganized or organized conglomerates of turbidite and debris flow origin. They are gradationally upwards into thin-to medium-bedded turbidites of top-cut Bouma's sequence. The last section is only medium-to thin-bedded turbidites associated with pebbly mudstones containing minor, contorted, folded and disrupted strata. The transitional nature of the turbidites to the pebbly mudstones (debris flow deposits) clearly indicates the sedimentary origin.

The dacite, andesite and basalt clasts in these pebbly mudstones are of calc-alkali series judging from their chemical composition and the compositional diagram of $\mathrm{SiO}_{2}$ vs $\mathrm{FeO} / \mathrm{MgO}$ and $\mathrm{TiO}_{2}$ vs $\mathrm{K}_{2} \mathrm{O}$ (Fig. 4). It is suggested that they were derived from the exposed volcanic arc terranes. The minor scale beds of coherent facies composed of thin interbeds of greenish tuff and black mudstone layers, interlayered within thickbedded sandstones, are observed in the chaotic facies of the Shimizu Formation exposed at the North of the Ban-yo Primary School and north of Kubotsu Village. This fact suggests that the chaotic facies also consists of the fragmented and broken strata of the coherent facies and to be formed by the "in-situ fragmentation" of CowaN (1985).

\section{Age determination}

Due to the scarcity of fossils and complicated structures of the Shimizu Formation, the age of the Shimizu Formation have long been uncertain. MASTuo (1980) reported plant fossils ranging from Oligocene to Middle Miocene from the thick-bedded sandstones near the central part of Tosashimizu City. Matsumaru and Kimura (1989) found larger foraminifera indicating Late Eocene at the northeast of Takahata Village, however, the strata exposed at this locality is now redefined as a part of the Kurusuno Formation mentioned above.

I found larger foraminifera fossils (Nephrolepidina morgani and Spiroclypeus sp., determined by MAtsumaru, personal communication, 1990) of late Oligocene or possible Early Miocene from the volcanic pebble-bearing mudstones exposed along the coastal benches, south of the Ohki beach. I further found Late Cretaceous radiolarian fossils from the pebbly mudstone from the coastal bench at $1 \mathrm{~km}$ south of Tsuro in the southern part of the study area (Myint Thein et al., 1991). Among them, Archeodictyomitra squinaboli ranges from Albian to Lower Campanian, and Protoxiphotractus perplexus is the index fossil of Crucella espartoensis Zone (Pessagno, 1976). The radiolarians range in age from Albian to Campanian (Myint Thein et al., 1991).

Thus, the strata of various ages are contaminated in the same formation, the age of the Shimizu Formation must be based on the fossils of the youngest strata or the youngest matrix.' No fossils were found from the matrix in this study, but it is at least certain that the age of the Shimizu Formation is not younger than the Lower Miocene (Burdigalian) which is the age of Misaki Formation (KImURA, 1985). Therefore, most of the Shimizu Formation represents the Oligocene or possibly Early Miocene, and the older clasts are included as exotic blocks. They might have been redeposited in the late Oligocene or Early Miocene. 


\section{Lithologic Facies, Sedimentary Facies and Interpretation}

Description of sedimentary rocks and interpretation of the sedimentary process and environments of the other formations in Shikoku has been done by the previous workers (KATTO and TAIRA 1978; TAIRA, 1981; KIMURA, 1985). However, there are no enough observation of sedimentary facies and the plausible depositional setting throughout the whole area of the Kurusuno and Shimizu Formations. Due to the structural intricacy, it is only possible to describe the original sedimentary facies of the coherent strata in these formations. Some continuous successions bounded by faults were selected as the measured sections to describe the facies association and to interpret their depostional environments. The localities of the columnar sections are shown in Fig. 5. The sedimentary facies is described by using the already proposed schemes of MUTTI and RICCI-LUCCHI (1978) and WALKER (1975). I adopted the classification scheme of sediment gravity flows as modified by Lowe (1982), degree of sorting of grains based on COMPTON (1962), bed thickness scales based on INGRAM (1954), and grain size descriptions based on Wentworth's Scales.

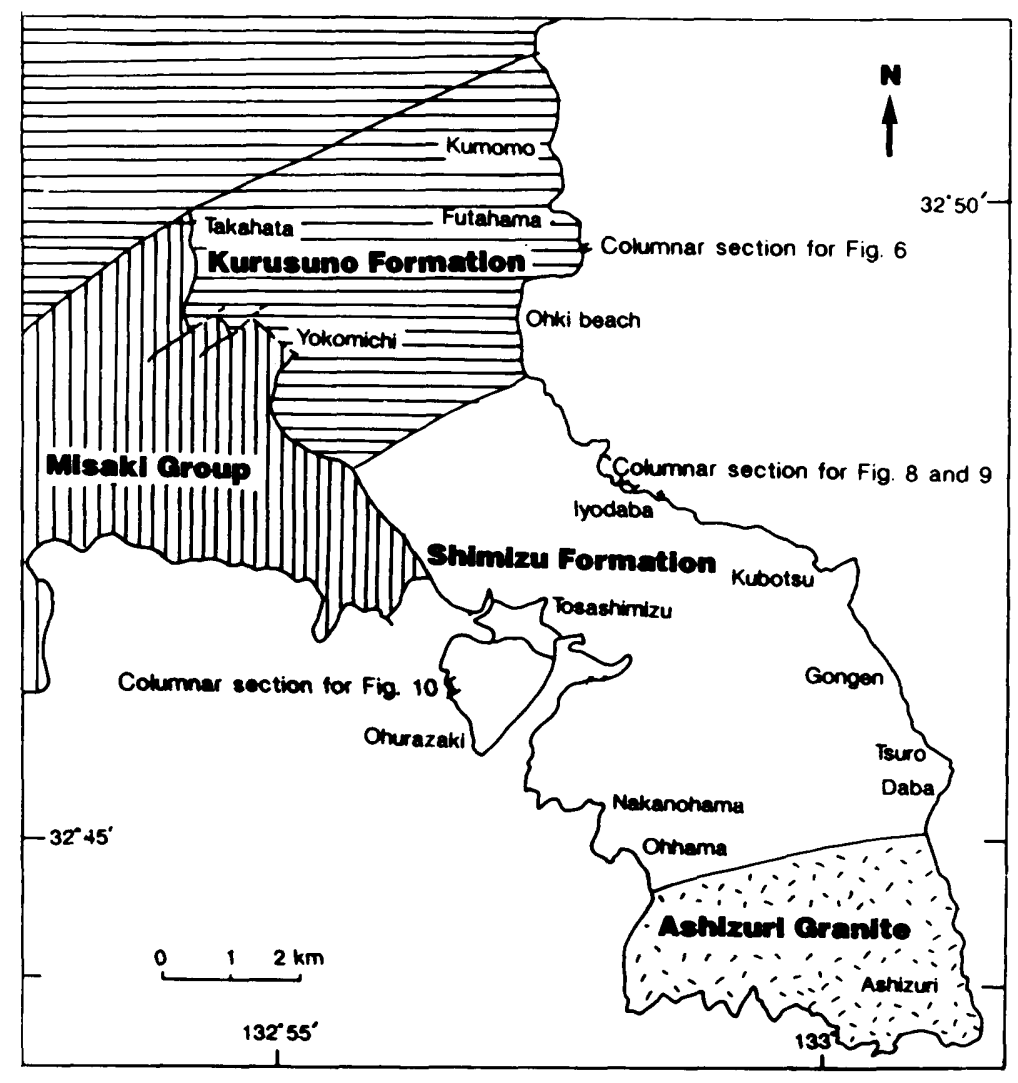

Fig. 5. Locality map of the stratigraphic measured sections of the Kurusuno and Shimizu Formations. 


\section{Coherent Facies of the Kurusuno Formation}

The coherent facies of the Kurusuno Formation is made up of two different lithologic sequences, channelized and non-channelized (Fig. 6).

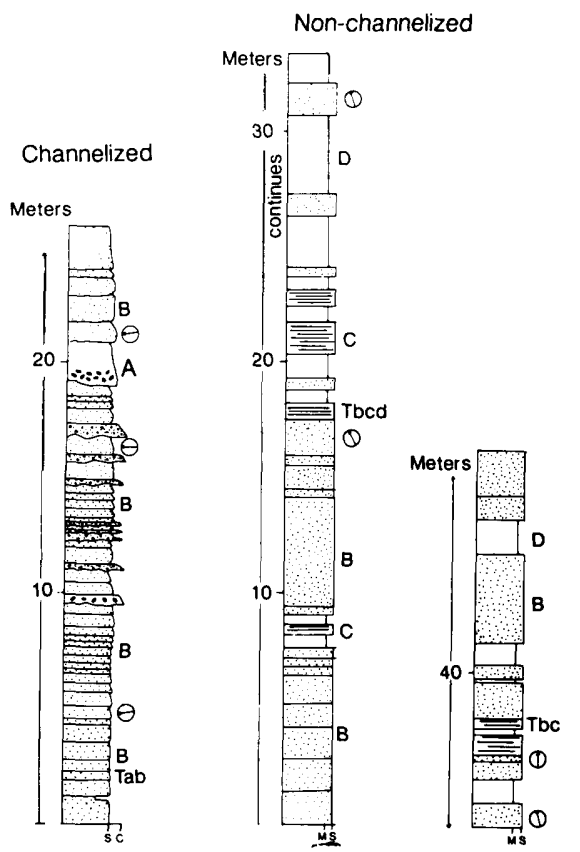

Fig. 6. Columnar sections of the channelized and the non-channelized sequence of the Kurusuno Formation. A to D indicate sedimentary facies described in the text. Tab etc are those of Bouma sequences. Arrow in the circle indicates paleocurrent direction; up is north. $\mathrm{M}, \mathrm{S}$ and $\mathrm{C}$ in the bottom of each column are sizes of sediments; mud, sand and pebble respectively.

The channelized sequence is distributed at the Pacific Ocean coastline, $1 \mathrm{~km}$ south from the Futahama beach. This sequence is made up of thick-bedded to massive $(40 \mathrm{~cm}$ to $>1 \mathrm{~m}$ ), coarse-grained, amalgamated pebbly sandstones (facies B). The base of the sandstone layer has mostly a trough scoured surface, and the top is sharp. The sandstone layers have top-cut Bouma sequence (lower structural divisions), hence, they might be proximal environment (HESSE, 1982). Some of the sandstone layers have a 7 or $8 \mathrm{~cm}$ thick zone of rip-up mud clasts at the base (Fig. 7-1). Paleocurrent data taken from flute cast at the base of the sandstone beds indicate that paleo-flow directed towards WNW. This channelized sequence is $25 \mathrm{~m}$ deep and incised the underlying highly contorted, folded and disrupted strata of the chaotic facies.

The non-channelized facies of the Kurusuno Formation is distributed at $0.5 \mathrm{~km}$ southeast from the village of Shimonagatani (Mihara Village). It is made up of thick-bedded to massive (2-3m), coarse-grained sandstone (facies B) alternated with interbeds of thin- to medium-bedded $(8-20 \mathrm{~cm})$ sandstone and mudstone (facies C \& D) (Fig. 7-2). The medium-bedded sandstone layers are cross-bedded and most beds grade up into mudstone. The sandstone layers are commonly amalgamated. The abundance of thick, amalgamated sandstones, and low angle cross-bedding also suggest 
their depostion in the proximal environment (HESse, 1982). The mudstone layers are thin $(2-5 \mathrm{~cm})$, mostly structureless, and some are parallel laminated. All of the sandstone layers have not only sharp base but also sharp top. The paleocurrent data from the cross-beds indicate that paleoflow directed towards $\mathrm{N}$ or NW of up-current flow. They do not exhibit the thick sedimentary cycles that characterise submarine fan deposits.
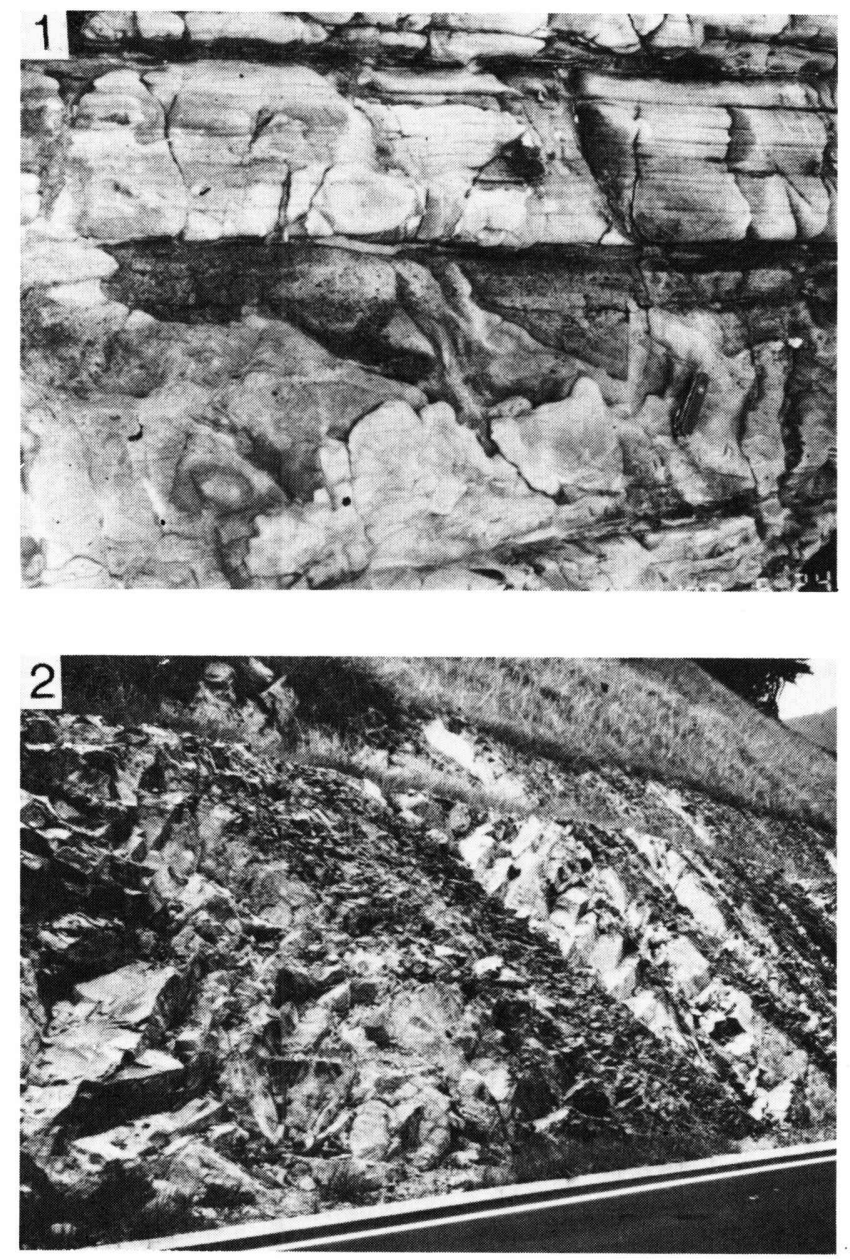

Fig. 7-1. Thick-bedded to massive sandstone (facies B) in the channelized sequence of the Kurusuno Fomation exposed on the coastline of Arizaki, north of the Ohki beach. Note that the basal trough scour surface and abundant rip-up mud clasts within the zone of 7 to 8 centimeters at the base.

-2. Thick-bedded to massive sandstone (facies B) alternated with interbed of mediumbedded sandstone and mudstone (facies $\mathrm{C}, \mathrm{D}$ ) in the non-channelized sequence of the Kurusuno Formation exposed on the coastline, 500 meters to the southeast from Yasugaichi Village. Note no erosional surface observed at the base and gradational contact at the top of thick sandstone bed. 
It is difficult to interpret the depositional setting of the Kurusuno Formation based only upon the facies association. The coarse grained, thick-bedded with poor development of grading, and sole markings, were called under the genetic name "fluxoturbidites" (Kuenen, 1958; Dzulynski et al., 1959). However, the term was later abandoned (WALKER, 1967). Stanly and UNRUG (1970) proposed that thick, coarse tongues of this type on outer submarine margins are referred to as submarine valley or submarine channel deposits. Hiscott (1980) and Leitch and CAwood (1980) interpreted that these ungraded beds are deposited by debris flow. It is postulated that they are submarine channel deposits that might be deposited on the slope, and base of slope and associated interbedded deposits are the overbank deposits of these channels. They are analogous to the Eocene Tanoguchi Formation exposed at the north of the study area (TAIRA, 1981).

\section{Coherent Facies of the Shimizu Formation}

The structural intricacy of the strata and the limited exposures reduce the accuracy of the interpretation of depositional setting. However, at least three facies associations are recognized; channel-fill facies association, slope basin facies association, and slope facies association (Figs. 8,9 and 10). No large scale asymmetric sedimentary cycles are recognized in the measured sections. On the other hand, the mud dominated sedimentary deposits in the whole sequence support the interpretation of a channel and a slope basin on a slope. The channel-fill association includes 10 to $15 \mathrm{~m}$ thick deposits of interbedded conglomerate, pebbly sandstone and sandstone with an erosional base. It is composed mainly of conglomerate (facies A), pebbly sandstone (facies B) and classical turbidite (facies C) deposits.
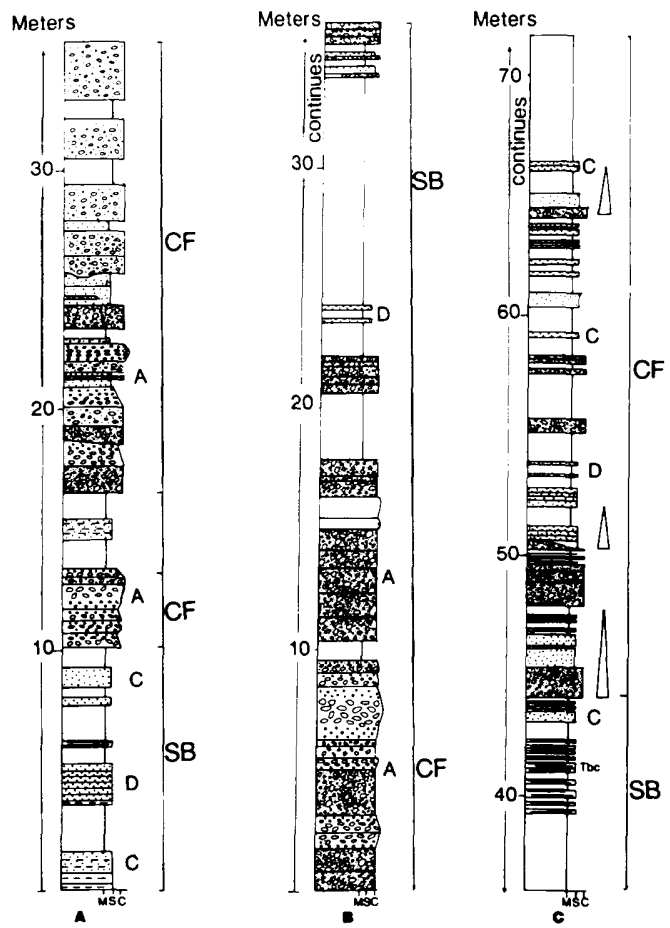

Fig. 8. Columnar sections of the coherent facies of the Shimizu Formation exposed near Iyodaba and Iburi Villages. 

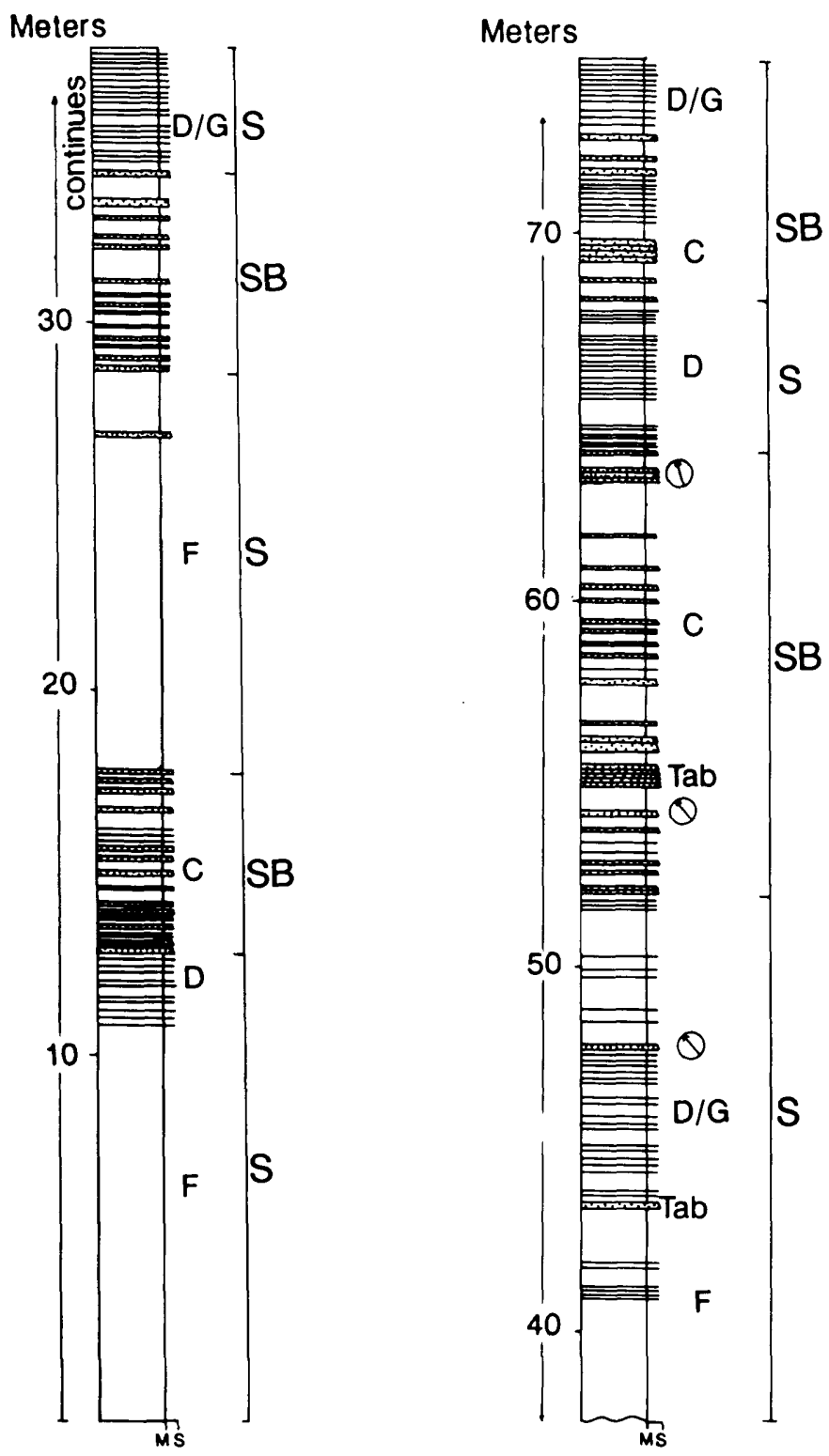

Fig. 9. Columnar sections of the coherent facies of the Shimizu Formation exposed near Iburi Village. 

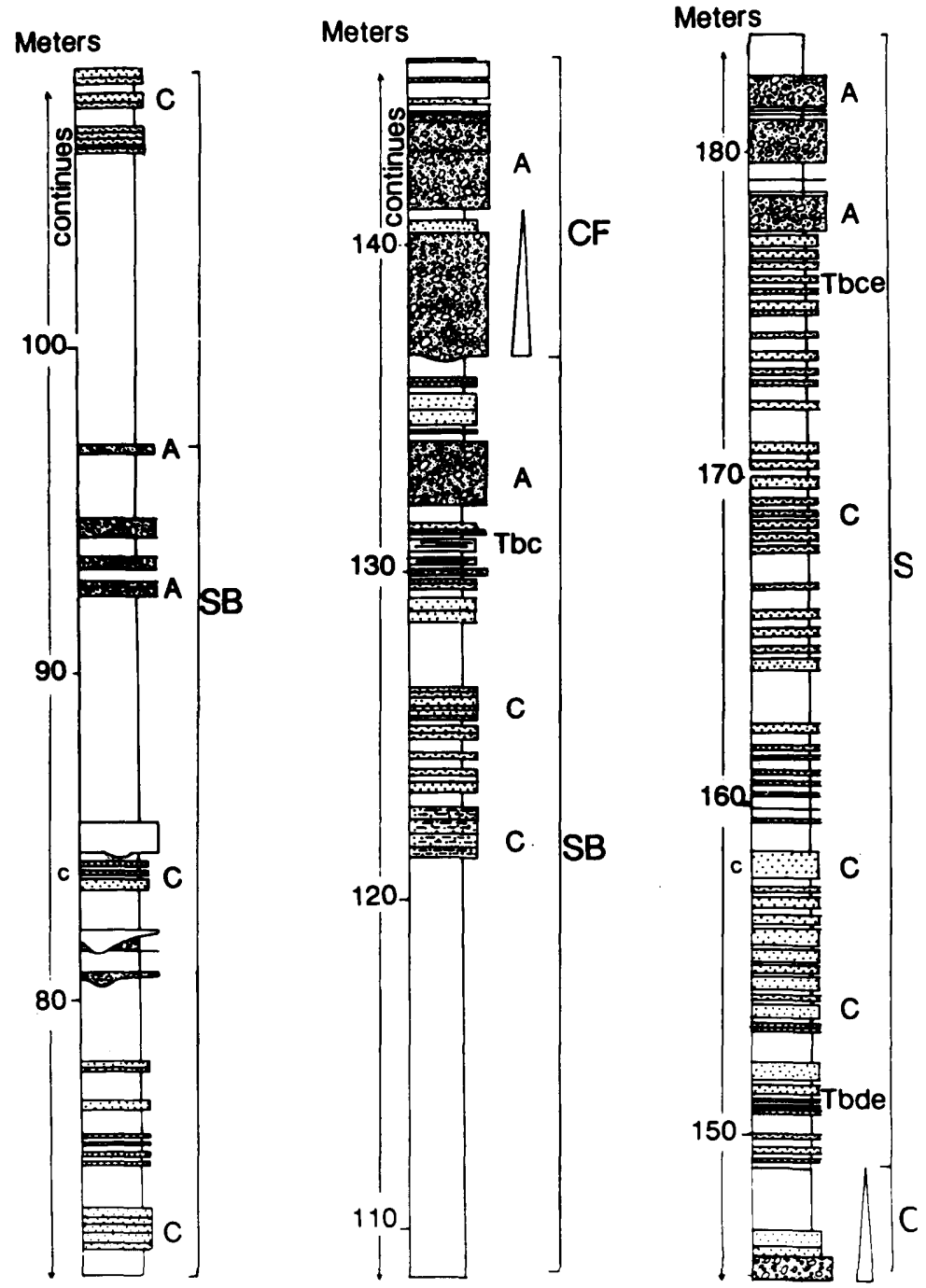

Fig. 10. Columnar sections of the coherent facies of the Shimizu Formation exposed on the coastline of Ohurasaki, south of Tosashimizu City. 
The conglomerate beds (facies A) are commonly amalgamated, and have mostly channelized bases. Clasts are rounded to subangular, equi-dimensional to prolate, and are composed of basalt and andesite with lesser amount of chert, quartzite and limestone. Bed thickness of conglomerate layers is highly variable, ranging from a few millimeters to $15 \mathrm{~cm}$. They can be subdivided into organized and disorganized-type
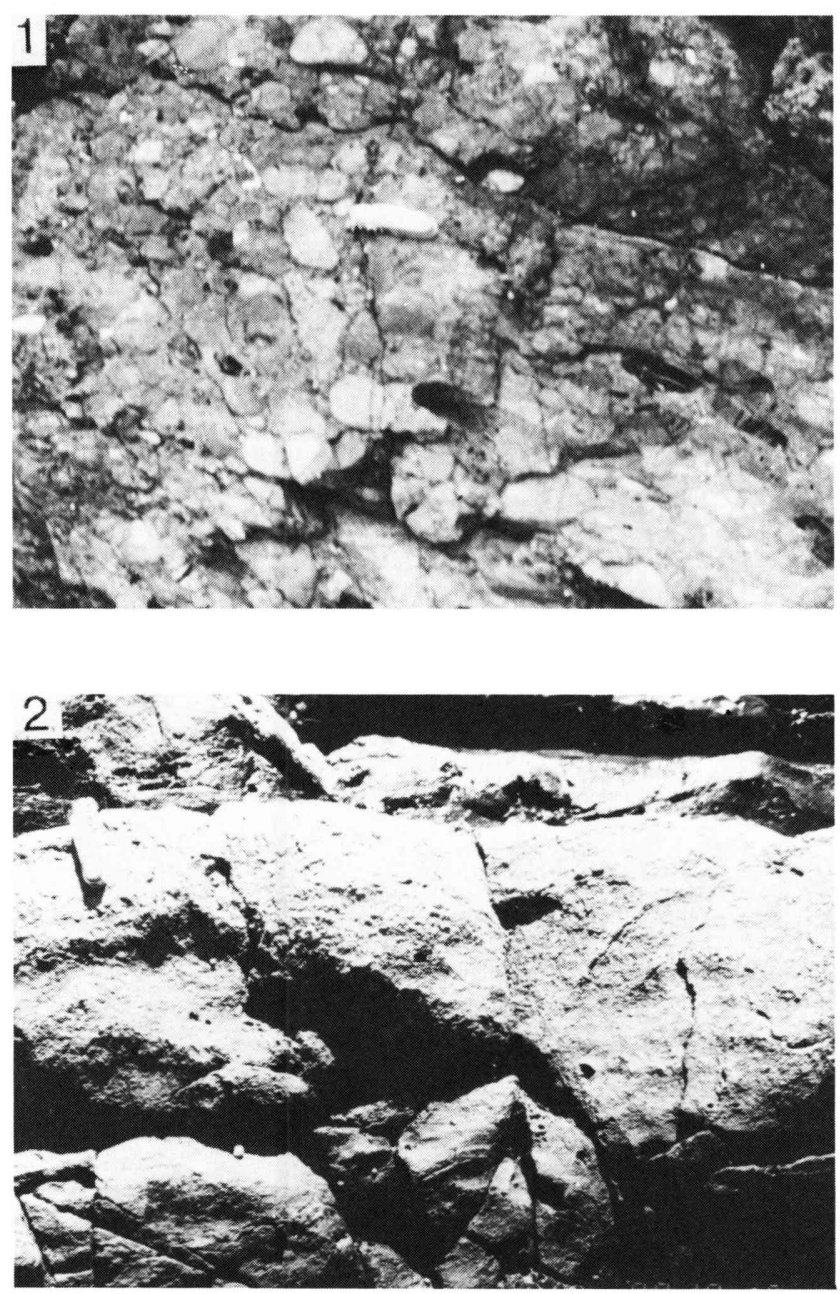

Fig. 11-1. Disorganized, clast supported conglomerate (facies A) in the coherent facies of the Shimizu Formation exposed on the coastline, 200 meters to south from Iburi Port. 'Note random fabrics of pebble- to cobble-size clasts embedded within the mud matrix.

-2. Organized, clast supported conglomerate (facies A) in the coherent facies of the Shimizu Formation exposed on the coastline, 200 meters to south from Iburi port. Note inverse-to-normal grading in the conglomerate bed. 


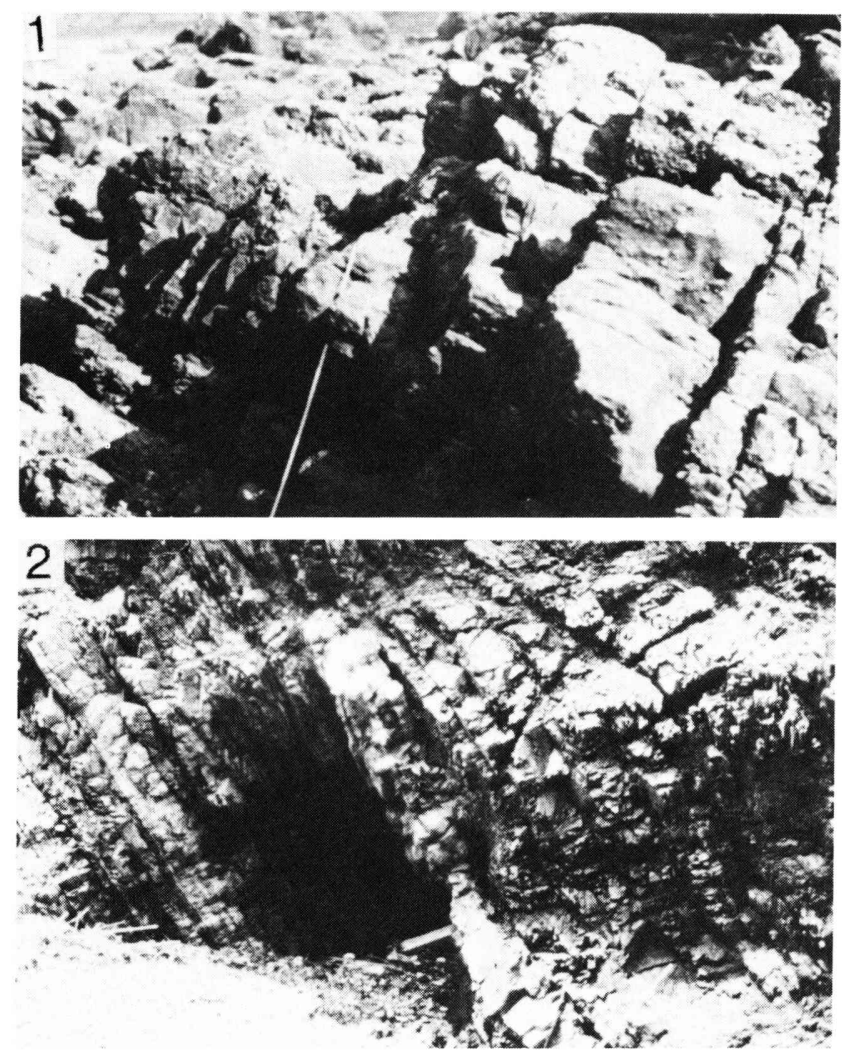

Fig. 12-1. Channelized, disorganized, matrix supported conglomerate (facies A) incising into the interbed of fine-grained sandstone and shale (facies $C$ and D). Locality is 500 meters to the south from Iyodaba Village.

2. Alternation of sandstone and mudstone of the slope basin association (facies $\mathrm{C}$ and D) in the coherent facies of the Shimizu Formation exposed on the coastline of Ohurazaki, south of the Tosashimizu City. Note coherent nature of the turbidites and their thickness.

conglomerates. Disorganized conglomerate layers have randomly oriented clasts (Fig. 11-1). Organized conglomerate layers display normal grading and rare inverse-to-nomal grading (Figs. 11-2). Pebbly sandstone beds (facies B) consist of thick, amalgamated sequence of massive, non-graded, fine- to medium-grained, gray to bluish-gray, sandstone beds. Bedding plane of the facies B sandstone is generally flat and sharp, and rarely with a channelized base. Classical turbidite beds (facies C) are composed of medium-to thick-bedded $(10-30 \mathrm{~cm})$, gray to bluish-gray sandstones, commonly a graded and parallel laminated division or top-cut Bouma sequence.

The slope basin association is characterized by sand-dominated facies $\mathrm{C}$ deposits that display distinct fining-upward sequences without an erosional base (Fig. 12-1). They also display a graded and laminated division or top cut-out Bouma sequence.

The slope facies association includes very thin- to thin-bedded turbidites of facies D and G, minor contorted and slump beds of facies F. Facies D beds are very thin- to thin-bedded (2 to $10 \mathrm{~cm}$ ), gray to bluish-gray sandstone beds. Average thickness of 
sandstone beds range from 2 to $4 \mathrm{~cm}$, whereas average thickness of interbedded mudstone beds (facies $\mathrm{G}$ ) range from 6 to $8 \mathrm{~cm}$. This facies $\mathrm{G}$ mudstone beds are characterized by planar bed and lateral continuity of bed thickness along strike (Fig. 11-2). The facies $\mathrm{F}$ beds consist of slump and debris flow deposits, and are well exposed in the northwestern part of the Ohurasaki Cape. Thickness of each slump and debris flow deposit ranges from 5 to 10 meters. Those beds are internally chaotic and highly disrupted zones of coherent turbidite beds of facies $\mathrm{C}$ and $\mathrm{D}$.

The channel-fill association is characterized by packets of coarse-grained sequences of facies $\mathrm{A}$, rare facies $\mathrm{C}$ deposits that cut into either fine-grained, thin-bedded sequences of facies $\mathrm{C}$ and $\mathrm{G}$ or sand-dominated, basin-fill sequences where the channelfill association incises sequences of facies $C$ and $G$ (Fig. 13). The transition from channel-fill association to overlying fine-grained deposits also occurs over a narrow (3 to $10 \mathrm{~m}$ ), fining and thinning-upward interval.

The slope basin association is characterized by sand-dominated facies $\mathrm{C}$ beds that display distinct thinning-and finning-upward sequences without erosional bases. Although, this vertical trends are characteristic of submarine fan-fringe or lobe-fringe deposits, it is interpreted that this sandy turbidites ponded in a small intra-slope basin.

The slope facies association is

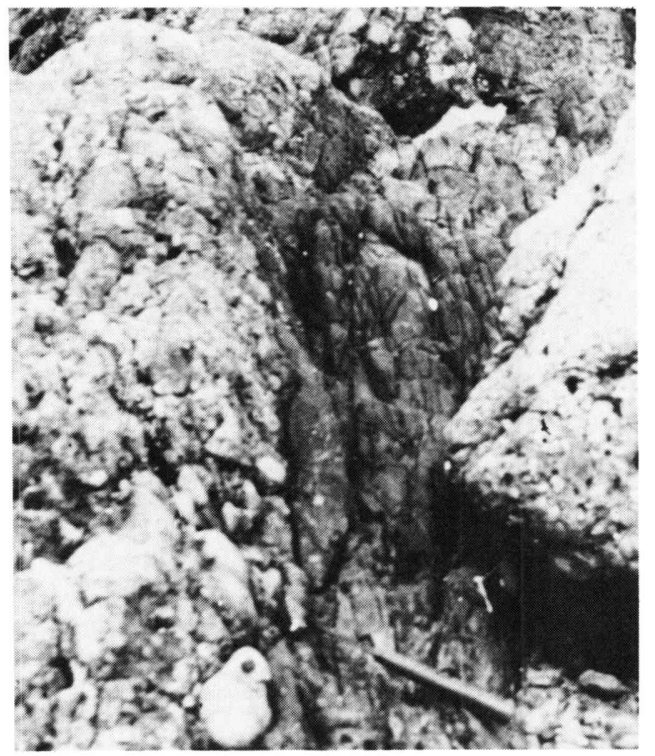

Fig. 13. The disorganized conglomerate beds (facies A) incising the slope mudstone (facies G). Note the original sedimentary contact and channelized portion of the conglomerate. characterized by very thin- and thin-bedded turbidite facies $\mathrm{C}, \mathrm{D}$ and $\mathrm{G}$ strata. This bedded turbidite of facies $\mathrm{C}, \mathrm{D}$ and $\mathrm{G}$ are found in many modern submarine fan environments(NELSON et al., 1978; MutTi, 1977). However, the lack of large scale $(>100 \mathrm{~m})$ vertical thinning- and fining-upward cycles representing the inner-, mid-, and outer-fan enviroments suggests that the facies association of the Shimizu Formation is not considered to be a part of a submarine fan. Debris flow deposits indicate deposition on an unstable slope. The abundance of fine-grained deposits of the slope facies association may reflect up-slope trapping of coarse-grained sediments and/ or bypassing of coarse-grained materials through submarine channels and canyons (UNDERWOOD and Bachman, 1982).

The Shimizu Formation is thus interpreted to represent gravitationally driven deposits on a submarine slope. This interpretation is based on the presence of finegrained, thin-bedded turbidites that contain minor slump beds, the relative abundance of debris flow deposits and local conglomerate deposits that incised a sequence composed 
predominantly of fine-grained turbidites.

- Rare paleocurrent data indicate the NW or NNW flow direction, suggesting the NW or NNW and possible local up-current flow direction.

\section{Chaotic Facies of the Kurusuno Formation}

\section{Fabric of Matrix}

Chaotic facies of the Kurusuno Formation presents a consistent pattern across the outcrops. The foliation generally strikes NE and dips mostly to NW or SE. It is characterized by closely spaced, millimeter-scale, "scaly foliation" throughout the entire
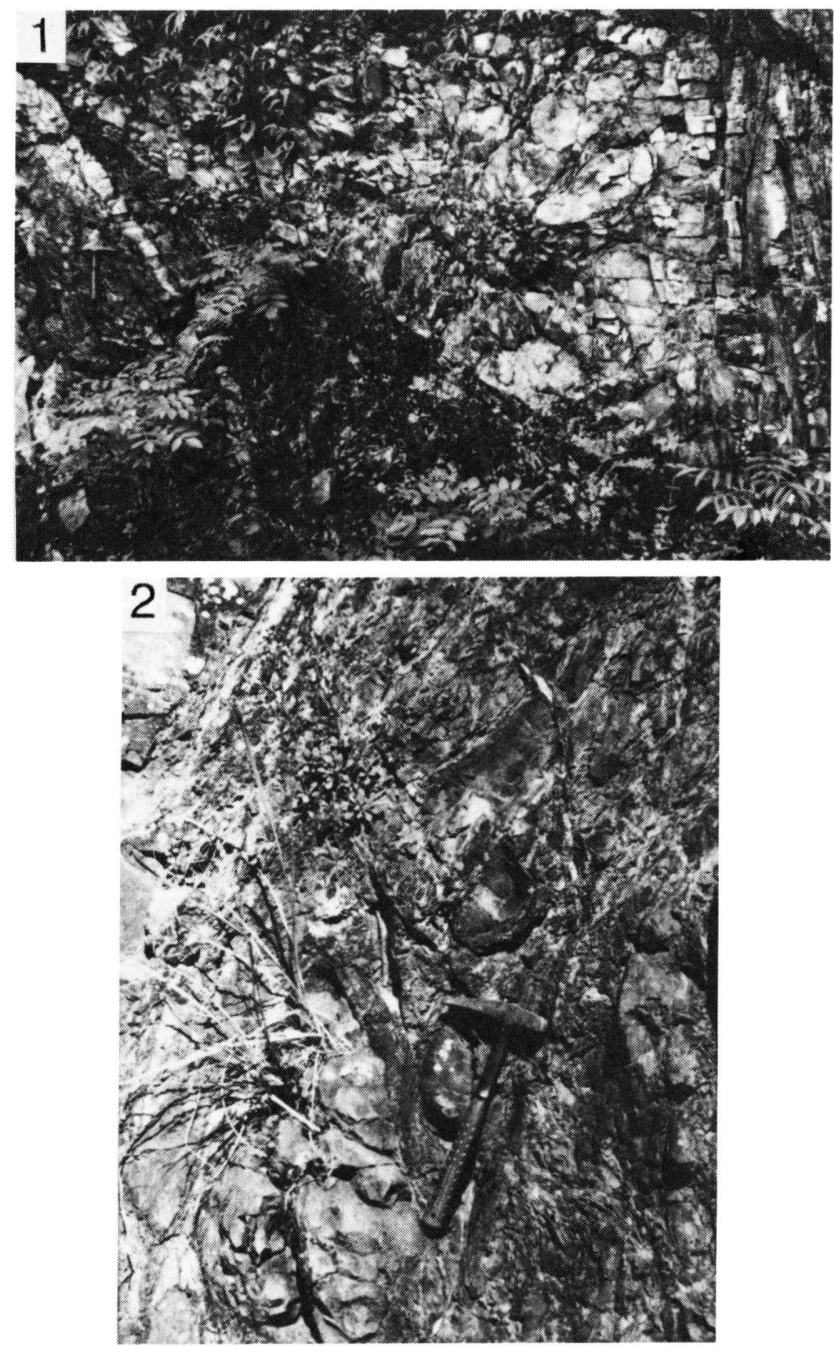

Fig. 14-1. The contact between the coherent and chaotic facies in the Kurusuno Formation. Note that the low angle thrust plane, and intense deformation of strata in the chaotic facies.

-2. Layer stretching or layer parallel extension of the strata in the chaotic facies of the Shimizu Formation. Note that the penetrative shear planes and scaly foliation. 
length of the exposure. The most intensely deformed matrix is well developed near or at the boundaries where it contacts with the rocks of coherent facies. The nature of this contact explains the juxtaposition of the coherent and the chaotic facies, and is interpreted as a low angle thrust (Fig. 14-1).

Small scale folds of SE vergence with a half wave length (limb separations) of 2-3 $\mathrm{m}$ and an amplitude of 7-8 $\mathrm{m}$ are developed. All of the folds are close (interlimb angles of 30-60 degrees) and nearly of parallel folds (class 1B to 1C of RAMSAY, 1967). Due to the pervasive shear and weak nature of the matrix, these folds may preserve only the latest deformation of the matrix.

Size, shape and composition of the clasts

Clasts are mainly thin to thick bedded, coarse grained sandstone, containing darkanastomosing surfaces, so called a "web structure". Exotic clasts such as volcanic tuff and tuff breccia can be traced at many places. Only at the Cape Zaimisaki, there are small clasts or layers of limestone, minor volcanic breccia and conglomerate. Some are channelized debris flow conglomerate with such clasts or layers, suggesting in-situ deposits. Most of the clasts or layers are irregular and phacoidal in shape near the margin of the chaotic deposits. Slicken-sided mudstone rinds are common in the chaotic deposits that are exposed beside the road-side cliff running parallel to the Kumomo and Kamogae Rivers. The smallest size of the clasts is approximately $1 \mathrm{~m} \times$ $15 \mathrm{~cm} \times 30 \mathrm{~cm}$, and the largest approximately $30 \mathrm{~m} \times 15 \mathrm{~m} \times 1 \mathrm{~m}$.

In a few cases, sandstone beds show a pinch and swell structure, extended by necking, resulting in lenticular bodies (Fig. 14-2). Some beds are thus in lenticular bodies, whereas others have extended along normal faults, forming discrete rotated blocks (comparing with extensional shear fractures in Cowan, 1982). They have retained their internal sedimentary structures, indicating a relatively brittle style of deformation, without pervasive flowage and thickening. Most of the clasts lie in the foliation and oriented with long axes approximately NE-SW which are coincident with the strike of the surrounding beds. It is difficult to determine whether this orientation was inherited from sedimentation or during deformation.

\section{Interpretation}

The chaotic facies of the Kurusuno Formation is characterized by a consistently oriented foliation, intense deformation throughout with a minor decrease in deformation toward the margins, consistent vergence of folding and thrusting. From the distribution of such rock facies, this rock unit can be interpreted as a melange (GREENLY, 1919) or shear-zone melange (ORANGE, 1990), a mud ridge (BREEN, et al, 1986), or an olistostrome. However, the exotic clasts of volcanic tuff, tuff breccia associated with turbidites and channelized conglomerate with rip-up mudstone clasts suggest that the primary mixing is due to the sedimentary process. The consistent SE dipping of fold axes, regional SE dipping pressure solution cleavage and local crenulation cleavage indicate that they were manifested and formed by the intense shear during accretion as discussed in the following chapter. 


\section{Chaotic Facies of the Shimizu Formation}

\section{Fabric of Matrix}

The chaotic facies of the Shimizu Formation is characterized by closely spaced, millimeter-scale, scaly foliation throughout the entire length of the exposure. Intensity of defommation is uniformly in the whole exposures. The development of the scaly foliation is commonly seen in thinly interbedded sandstone and shale, and decreases near thick-bedded sandstone or conglomerate. Some wisps of volcanic tuff or tuff breccia or conglomerate indicate the similar behavior as the matrix. The mechanical properties of these disharmonic tuff layers must have been similar to the mudstone matrix. Such evidence for extremely ductile, cohesive flow suggests that at least some of the deformation occurred while the mud and tuff were only partly dewatered and consolidated.

Isoclinal, intrafolial folds of outcrop scale are commonly observed in the chaotic facies of the Shimizu Formation. Some open and parallel style folds (class B of RAMSAY (1967)) associated with weak axial planar pressure solution cleavage are developed in the chaotic facies. The cleavage cuts or transposes the primary disruption. Sometimes the transposition ranges from 1-2 meters, fold amplitude 50-80 centimeters.

\section{Size, shape and composition of the clasts}

Within the chaotic facies of the Shimizu Formation, shape of clasts varies from angular to phacoidal. The chaotic facies of the Shimizu Formation is described as simply a broken, fragmented and disrupted sedimentary sequence or a "broken formation" rather than a "clasts-in-matrix melange". It consists of a chaotic assemblage of three types : (1) medium to thick-bedded turbidites with minor channelized bodies of clast-supported conglomerates with basal rip-up mud clast zone, being interpreted as debris flow deposits, (2) thin interbeds of sandstone and shale, (3) minor clasts of volcanic tuff, tuff breccia, volcanic conglomerate and sandstone which occur as wisps in mudmatrix. The isolated and irregular shaped clasts of thin interbed of sandstone and mudstone are common (Fig. 15-1).

The size of the clasts ranges from millimeter to tens of meter in length. Most are less than a meter, the largest clast is approximately $15 \mathrm{~m} \times 10 \mathrm{~m} \times 5 \mathrm{~m}$ (Fig. 15-2). Most of the strata show necking, pinch and swell, and boudin. They are commonly fractured and filled with calcite or quartz veins. Most of the veins do not crosscut the mudstone matrix. Some clasts display jigsaw puzzle structures (PICKering et al., 1989). Their internal structures explain the cataclasis with overprinted pressure solution of the later stage. They are thought to be formed by the process analogous to in-situ layer fragmentation suggested by Cowan (1985). 

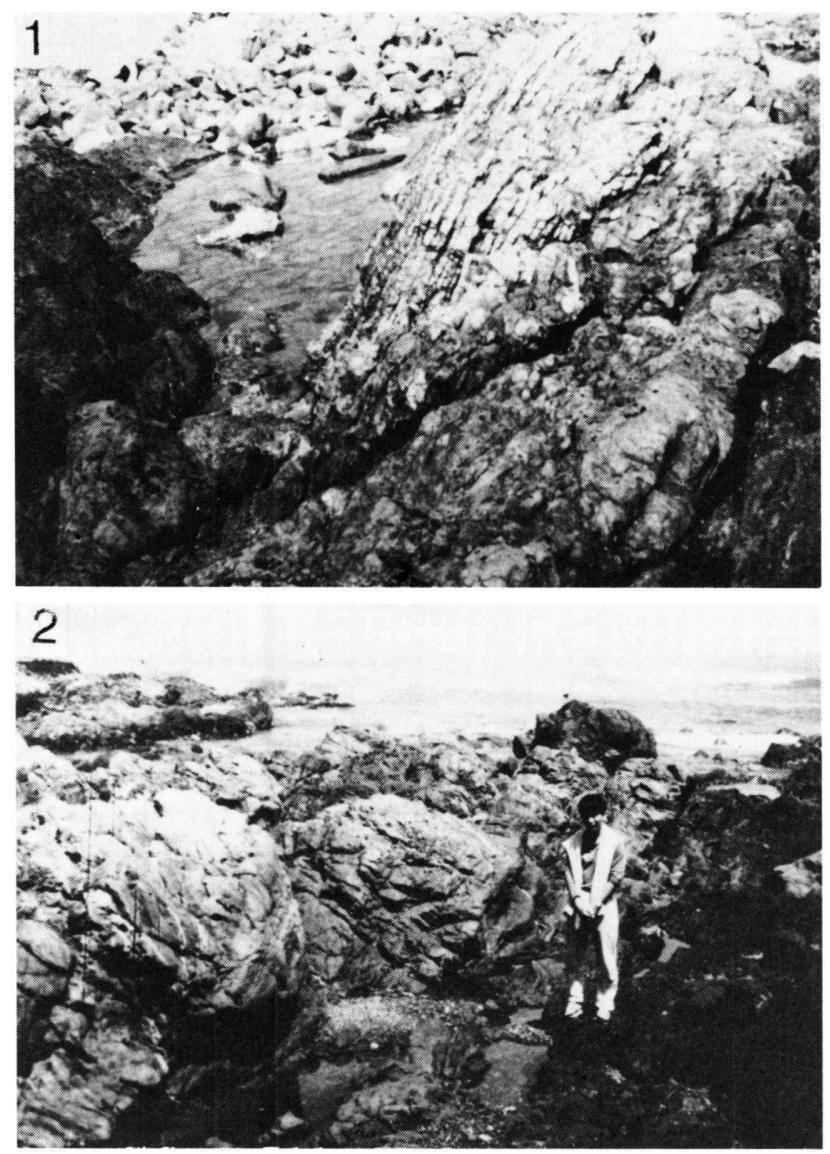

Fig. 15-1. Thin interbed of sandstone and shale occurs as clast in the chaotic facies of the Shimizu Formation. Note that all of the clasts are clastic sedimentary rocks composed mainly of sandstone, interbed of sandstone and mudstone.

-2. The field occurrence of the chaotic strata in the chaotic facies of the Shimizu Formation. Note that different sizes of clasts.

\section{Interpretation}

The chaotic facies of the Shimizu Formation is characterized by the consistent foliation that trends NE-SW or NNE-SSW and dipping toward the NW-SE or NNWSSE. The orientation of smaller clasts and the shape of their irregular margins show no preferred alignment. The slaty cleavage, characterized by pressure solution, cuts the previous soft sediment folds. The deformation features at random angles are also recognized.

It is considered that the gravity driven down slope stretching led to the developments of internally chaotic debris flows, slides or slumps which occurred primarily as an olistostrome. 


\section{Discussion}

A submarine steep slope and base of slope setting provides a useful model for interpretation of sedimentary facies and structural fabrics of the Kurusuno Formation. Thickly bedded, proximal turbidites and interbeds of thin sandstone and mudstone commonly deformed by soft-sediment folding are associated with the chaotic facies in the Kurusuno Formation. The deformed and disrupted or fragmented beds are bounded above and below by undisturbed, parallel graded beds; deformation is thus clearly not tectonic in origin. The very coarse and graded pebbly sandstone beds $(0.5$ to $1.5 \mathrm{~m}$ thick) is typical of proximal turbidites. Most of the Kurusuno Formation consists of turbidites represented by the Bouma sequence $\mathrm{Ta}$ (graded division) and $\mathrm{Tb}$ (parallel laminated divition). It is not common to have amalgamated graded sandstones without intervening mudstones. The magmatic arc provided compositionally immature sediments and occur as the source for large olistoliths or clasts of volcanic rocks, such as seen at the Cape Zaimisaki. It is likely that rivers and gravity mass flow processes delivered an assortment of rounded clasts to a narrow shelf edge where they were deposited at or near the top of a rugged slope. These debris flows incorporated blocks of basement rocks along with mudstone and sandstone of the shelf edge and slope (Fig. 16).

The Shimizu Formation contains mega-olistoliths within debris flows of indeterminate vertical and lateral dimensions. Debris flows that continued such bodies would have been $100 \mathrm{~m}$ to $500 \mathrm{~m}$ thick, and at least several kilometers in lateral extent, and probaly much larger. To produce such a debris flow, a major portion of the slope or proximal basin margin, perhaps as high as to shelf-break, would have to fail and collapse (Fig. 16).

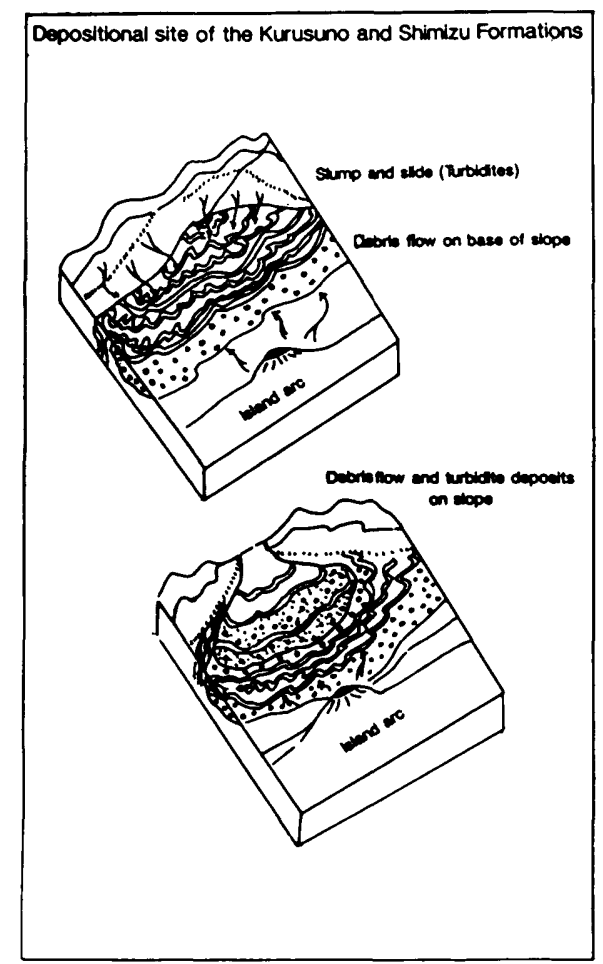

Fig. 16. Schematic reconstruction of bird's eye view of the Kurusuno (upper) and Shimizu (lower) Formation. 
The resulting slide blocks would probably initially remain intact, but depending on basal and internal shear, distance of transportation and shear strength would make the internal fragments to a greater or lesser degree.

It is proposed here that large sediment gravity slides and debris flows were responsible for the the transport of olistoliths. These flows were probably intiated on the middle or upper parts of a steep submarine slope. Submarine slides initially moved as large blocks or masses along basal shear surfaces. As the blocks accelerated down slope, they were more or less intensively deformed and, in part, sheared internally and mixed with slope muds and turbidites. Those conditions led to form the pebbly mudstones which are characteristic of slope environments (STANLAY and UNRUG, 1972), and have been observed in modern submarine channels (GoRSLINE and EMERY, 1959; StANLAy, 1974). Emplacement mechanisms for pebbly mudstones include the downslope slumping of coarse clasts in a water saturated mud matrix. This slumping is thought to occur as a very viscous flow which just surpassed its liquid limit, but regained cohesion thixotropically before a true turbidity current developed (CROWELL, 1957; DoT,T 1963). Some blocks maintained a degree of coherence were thus introduced into the lower slope environment, as large stratifom sheets. The margin of such masses may be considerably deformed, but the interior remained relatively undeformed and homogeneous. Other slide masses were much more strongly sheared throughout. These disrupted blocks were stretched and fragmented while enclosed in a soft-sediment matrix within these large debris flows, mega-olistoliths were supported by a rigid or semirigid plug in the center of debris flow (Johnson, 1970; Johnson and Rodine, 1984). These flows moved on basal shear surfaces or zones and supported clasts of immense size.

It is postulated that the formation of large scale olistostrome of a slope or base of slope, however, slides and debris flows require only a steep slope enough for gravitational transport. The olistostrome development is related to the rifting and opening of the Shikoku Basin (SAKAI, 1988). Geophysical and stratigraphic evidence of rifting of the basin shows that it was initiated in the Late Oligocene between 30 and $25 \mathrm{MaBP}$, and the opening was completed by the early Middle Miocene between 15 and $18 \mathrm{MaBP}$ (Kobayashi, 1983; Seno and Maruyama, 1984). The gravity instability of the basin is inferred to be triggered by a strong drag of hanging plate corresponding to initiation of Chile type subduction of the Shikoku Basin. Continental supply of large olistostrome into the trench and following rapid growth of accretionary prism induced uplift of the landward slope of the trench. This catastrophic events may be represented by the Takachiho orogeny (SAKAI, 1988). The accreted and uplifted zone became a basement of forearc basin in at least $14 \mathrm{MaBP}$ (SAKAI, 1988) up to the deposition of the Misaki Group which consists of the typical shallow marine deposits (KImURA, 1985).

\section{Acknowledgements}

This paper is a part of $\mathrm{Ph}$. D thesis submitted to Kyushu University, Fukuoka, Japan. I am imdebted to my supervisor, Prof. Yujiro OGAWA, who led to progress of this study. Also, I am grateful to Profs. Hakuyu OKada and Atsuo Ainara who read the draft of this paper. I would like to thank to Emeritus Prof. Kametoshi Kanmera and Mr. Takashi SAKAI, who gave me knowledge and stimulated discussions of sedimentary approches in melange terranes. Acknowledgments are also for the reviewer of the draft. Financial support is provided by Ministry of Education (Monbusho) of Japan. 


\section{References}

Breen, N. A., Silver, E. A., and Hussony, D. M. (1986) : Structural style of an accretionary wedge south of the island of Sumba, Indonesia, revealed by Sea MARC II side scan sonar. Bull., Geol. Soc. Amer, 97, 1250-1261.

Compton, R. R. (1962) : Manual of Field Geology. New York, Wiley, 378p.

Cowan, D. S. (1982) : Deformation of partly dewartered and consolidated Franciscan sediments near Piedra Blanca Point, California. In: J. K. LEGGETT ed., Trench-Forearc Geology. Spec. Geol. Soc. London Publ. 10, 439-458.

- (1985) : Structural styles in Mesozoic and Cenozoic Melanges in the Western Cordillera of North America. Bull. Geol. Soc. Amer., 96, 451-463

Growell, J. C. (1957) : Origin of pebbly mudstones. Bull., Geol. Soc. Amer, 68, 993-1010.

Dotт, R. H., (1963) : Dynamics of subaqueous gravity depositional processes. Bull., Amer. Assoc. Petr. Geol., 47, 104-128.

DotT, R. H., and BIRD, K. J. (1979) : Sand transport through channels across an Eocene shelf and slope in southwestern Oregon, U. S. A. In : Doyle, L. J., and PilkY, O. H., eds., Geology of Continental Slopes. Soc. Econ. Paleontologists \& Mineralogists, Spec. Publ., $27,327-342$.

Dzulynski, S., Ksiazkiewicz, M., and Kuenen, PH. H. (1959) : Turbidites in flysch of the Polish Carpathian Mountains. Bull., Geol. Soc. Amer., 70, 1089-1118.

GorsLine, D. S., and Emery, K. O. (1959) : Turbidity Current deposits in San Pedro and Santa Monica basin of southern California. Bull., Geol. Soc. Amer., 70. 279-290.

Greenly, E. (1919): The Geology of Anglessey. Mem., Geol. Surv. Great Britain, 1.

HiscotT, R. H. (1980) : Depositional framework of sandy mid-fan complexes of Tourelln, Ordovician, Quebec. Bull., Amer. Assoc. Petr. Geol., 64, 1052-1077.

HESSE, R. (1982) : Flysch zone of East Alps and Garpathians. In: J. K. Leggett, ed., Trench Forearc Geology. Geol. Soc. London, Spec. Publ. 10, 471-494.

INGRAM, J. (1954) : Terminology for the thickness of stratification and parting units in sedimentary rocks. Bull., Geol. Soc. Amer., 65, 937-938.

Johnson, A. M. (1970) : Physical processes in Geology. Sun Francisco, Freeman Publ. Co., $571 \mathrm{p}$.

Johnson, A. M., and Rodine, J. R. (1984) : Debris flow. In : Brunsden, D., and P D. B., eds., Slope instability. New York, John Wily and Sons, 275-361.

KANMERA, K. (1977) : General aspect and recognition of olistostromes in the geosynclinal sequence. Monograph, Assoc. Geol. Gollab., Japan, 20, 145-159.

Karig, D. E., Cardwell, R. K., and Moore, G. F. (1978) : Late Cenozoic subduction and continetal margin truncation along the northern Middle America trench. Bull., Geol. Soc. Amer., 89, 265-276.

KatTo, J. (1961) : Some problematica from the so-called unknown Mesozoic strata on the southern part of Shikoku, Japan. Sci. Rept., Tohoku Univ., Spec. 4, 323-334.

(in Japanese with English abstract)

Katto, J., and Mitsui, S. (1976) : On the Kurusuno Formation in the southern area of Nakasuji Graben, southwestern Shikoku, Japan. Bull., Nat. Sci. Museum 9, 35-37. (in Japanese with English abstract)

Katto, J., and TAIRA, A. (1978) : Rock facies and depositional environment of Murotohanto Group. Geol. News, 287, 21-31.

Katto, J. (1980) : Recent progress on biostratigraphy of the Shimanto Belt. in:TAIRA, A., and TAshiro, M., eds., Geology and Paleontology of the Shimanto Belts. 
Rinyakosakai Press, Kochi, 299-318. (in Japanese with English abatract)

KIMURA, K. (1985) : Stratigraphy and sedimentary facies of the Tertiary Shimizu and Misaki Formations in the southeastern part of Shikoku. Jour. Geol. Soc. Japan, 91, 815-831. (in Japanese with English abatract)

Kobayashi, K., and NaKadA, M. (1978) : Magnetic and tectonic evolution of the Shikoku inter-arc basin. Jour. Phys. and Earth, 26, 291-402.

Kobayashi, K. (1983) : Cycles of subduction and Cenozoic arc activity in the northwestern Pacific margin. In : HILDE, T. W. C., and UYEDA, S., eds., Geodynamics of the western Pacific. Geol. Soc. Amer., Geodynamics Ser. 9, 287-302.

KuENEN, PH. H. (1958) : Problems concerning source and transportation of flysch sediments. Geologie en Mijnbouw, 20, 329-339.

Leitch, E. C. and Compton, P. A. (1980) : Olistoliths and debris flow deposits at ancient consuming plate margins : An eastern Australian example. Sedimentary Geology 25. 5-22

Lowe, D. R. (1982) : Sediment Gravity Flow, II. Depositional models with special reference to the deposits of high-density currents. Jour. Sedimentary Petrology, 52, 279-297.

Matsumaru, K. (1980) : On the genus Asterocy clina from the Kurusuno Formation, Tosa shimizu City, Kochi Prefecture, Shikoku, Japan. In: TAIrA, A., and TASHIRo, M., eds., Geology and Paleontology of the Shimanto Belts. Rinyakosaikai Press, Kochi, Japan, 217-218. (in Japanese with English abstract)

Matsumaru, K., and Kimura, K. (1989) : Larger foraminifera from the Eocene Shimizu and Misaki Formations in Tosashimizu City, Kochi, Shikoku, Japan. Trans. \& Proc. Paleont. Soc. Japan, 156, 255-269.

Matsuo, H. (1980) : On the phytofossils from the so-called Shimanto Belt. In : Taira, A., and TASHIRo, M., eds., Geology and Paleontology of the Shimannto Belts. Rinyakosaikai Press, Kochi, Japan, 247-249. (in Japanese with English abstract)

MCGREGOR, B. A., and BenNet, R. H. (1979) : Mass movement of sediment, on the continental slope and rise seaward of the Baltimore Canyon Trough. Marine Geol., 33, 163-174.

Moore, G. F., and Karig, D. E. (1980): Structural geology of Nias Island, Indonesia. Bull. Amer. Assoc. Petr. Geol., 70, 1729-1741.

MutT, E. (1977) : Distinctive thin-bedded turbidite facies and related depositional environments in the Eocene Hecho Group (south-central Pyrenees, Spain). Sedimentology, 24, 107-131.

MutTI, E., and RICCI-LucchI, F. (1978) : Introduction to facies analysis : In: Turbidites of the Northern Appennines (transl. by Nilsen, T. H. ). Amer. Geol. Inst. Reprint Ser. 3, 167p.

Myint Thein., Ogawa, Y., Akiyama, T. (1991) : Finding of Cretaceous radiolarians from the block of sheared olistostrome in the southern part of the Shimanto Belt near the Ashizuri Cape, Kochi Prefecture. Jour. Geol. Soc. Japan, 97, 667-669.

Nelson, H., Normark, W. R, Bouma, A. F., and Garlson, P. R. (1978) : Thin bedded turbidites in modern submarine canyons and fans. In: Stanlay, D. J., and Kelling, G., eds., Submarine Canyons, Fans and Trenches. Stroudsburg, Pennsylvania, Dowden, Hutchinson and Poss, 177-189.

Nishi, T. (1990) : Reconsruction of the ancient accretionary complex. An example from the Sanbosan Belt. Ph. D., thesis, Depart. Geol. Kyushu Univ., 132p.

OGawa, T. (1902) : Geological map of Kochi, Geol. Surv. Japan.

ORANGE, D. L. (1990) : Criteria helpful in recognizing shear zone and diapiric melanges: Examples from the Hoh accretionary complex, Olympic Peninsula. Bull., Geol, Soc. Amer., 102, 935-951. 
Pessagno, E. A. (1976) : Radiolaria zonation and stratigraphy of the Great Valley sequence, California Coast Ranges. Micropaleont., Spec. Publ. 2, 1-95.

Pickering, K. T., Agar, S. M., and Ogawa, Y. (1988) : Genesis and deformation of mud injections containing basalt-limestone and chert association : Example from the SW Japan forearc. Geol. 16, 881-8853.

Ramsay, J. G. (1967) : Folding and fracturing of rocks : San Francisco, California, Mc. Graw Hill, $568 \mathrm{p}$

SAKAI, T. (1983) : The outer margin olistostrome belt of the Shimanto terrane in tectonic relation to Southwest Japan and the Philippine Sea Plate. Spec. Publ., Nishinihon Branch, Geol. Soc. Japan, 83-87. (in Japanese with English abstract)

SAKAI, H. (1988) : Origin of the Misaki Olistostrome Belt and re-examination of the Takachiho Orogeny. Jour. Geol. Soc. Japan, 94, 945-961. (in Japanese with English abstract).

Seno, T., and Maruyama, S. (1984) : Paleogeographic reconstruction and origin of the Philippine Sea. Tectonophys., 102, 53-84.

STANLEY, D. J., and UnRUG, R. (1972) : Submarine channel deposits, fluxoturbidites and other indicators of slope and base of slope deposits. In : RightRY, J. K., and HAMBLIM, Wm. K., eds., Recognition of ancient sedimentary environments. Soc. Econ. Paleontologists \& Mineralogists., Spec. Publ., 19, 287-340.

Stanley, D. J. (1974) : Pebbly mud transport in the head of Wilmington Canyon. Marine Geol., 16, M1-M8.

Suzuki, T., and HadA, S. (1979) : Cretaceous tectonic melange of the Shimanto Belt in Shikoku, Japan. Jour. Geol. Soc. Japan, 85, 467-479.

Taira, A., Okamura, M., Katto, J., Tashiro, M., Saito, Y., Kodama, K., Hashimoto, M., CHIBA, T., and AoKI, T. (1980) : Lithofacies and geologic age ralationship within melange zone of the northern Shimanto Belt. In : TAIRA, A., and TASHIRo, M., eds., Geology and Paleontology of the Shimanto Belt, Kochi, Japan, Rinyakosaikai Press, Kochi, Japan, 179-214. (in Japanese with English abstract)

TAIRA, A. (1981) : The Shimanto Belt of southwest Japan and arc-trench sedimentary tectonics. Recent Prog. Nat. Sci. Japan, 6, 147-152.

Taira, A., Okada, H., Smith, A. J., and Whitetaker, J. H. (1982) : The Shimanto Belt of Japan. Cretaceous-Lower Miocene active margin sedimentation. In : LEGGETT J. K. ed., Trench-Forearc Geology. Ged, Soc, London, Spec, Publ., 10, 5-26

Taira, A. (1985): Pre-Neogene accretion tectonics in Japan. A. synthesis. Recent Prog. Nat. Sci. Japan, 51-64.

TAKAHASHI, M. (1980) : Voluminous felsic magma activity and upper crust formation in the mobile zone. Earth Monthly (Chikyu), 2, 837-845. (in Japanese)

Underwood, M. B and BACHMAN, S. B. (1982) : Sedimentary facies associations within subduction complexes. In: Leggett, J. K., ed., Trench-Forearc Geology. Geol. Soc. London, Spec. Publ., 10, 537-550.

WALKER, R. G. (1967) : Turbidite sedimentary strucsures and their relationship to proximal to distal depositional environments. Jour. Sedimentary Petrology, 37, 25-43.

- (1975) : Generalized facies models for re-sedimented conglomerates of turbidite association. Bull., Geol. Soc. Amer., 86, 737-718. 